\title{
Strategie „komunizacji” przeciwnika politycznego. Obraz środowiska Unii Wolności w dyskursie polskiej prawicy ${ }^{1}$
}

\begin{abstract}
Streszczenie: Unia Wolności, mimo swojej wieloletniej nieobecności na scenie politycznej, nadal wykorzystywana bywa jako dyskursywna figura służąca polaryzacji debaty publicznej i polityki partyjnej oraz dyskredytowaniu oponentów politycznych. Celem niniejszego tekstu jest ukazanie genealogii oraz analiza specyficznych treści budujących strategię delegitymizacji przy użyciu figury Unii Wolności. Zadanie to realizowane będzie poprzez analizę szczegółowych strategii budowania wizerunku środowiska UW i jej poprzedniczek: Ruchu Obywatelskiego Akcji Demokratycznej oraz Unii Demokratycznej podejmowanych przez ugrupowania prawicowe.
\end{abstract}

Slowa kluczowe: konstruowanie wroga politycznego, partie polityczne, Unia Wolności, dyskurs

$\mathbf{U}^{2}$ nia Wolności, mimo swojej wieloletniej nieobecności na scenie politycznej, z której zeszła po serii klęsk wyborczych, błędów strategicznych i wewnętrznych podziałów, nadal wykorzystywana bywa jako dyskursywna figura służąca polaryzacji debaty publicznej i polityki partyjnej oraz dyskredytowaniu oponentów politycznych. W marcu 2015 r., u progu kampanii prezydenckiej tygodnik „Newsweek” opublikował artykuł, informujący o tym, że Andrzej Duda, kandydat Prawa i Sprawiedliwości, był członkiem Unii Wolności w latach 2001-2002. Świadczyć o tym miały dokumenty małopolskiej Unii Wolności znalezione przez dziennikarzy tygodnika w Archiwum Narodowym: wykaz małopolskich struktur terenowych i osób w nich działających, podpis na liście obecności na III Zjeździe Regionalnym Małopolskiej UW, a także potwierdzenie, że A. Duda opłacił składki członkowskie w 2002 r. (Szulc, Krzymowski, 2015, s. 20). Co istotne dla sprawy, o fakcie tym milczał oficjalny życiorys kandydata, który wspominał jedynie o jego zaangażowaniu w kampanię wyborczą 1989 r., a następnie działalności politycz-

1 Tytuł artykułu posługuje się nazwą Unii Wolności jako nazwą ostatniej formy organizacyjnej, którą przyjęło środowisko polityczne, negocjujące przy Okrąłym Stole, skupione m.in. wokół T. Mazowieckiego, B. Geremka, J. Kuronia, czy A. Michnika, tworzące Ruch Obywatelski Akcję Demokratyczną (od 16 lipca 1990 r. - ogłoszenie „Deklaracji”), wspierające rząd T. Mazowieckiego oraz jego starania o objęcie urzędu prezydenta w kampanii wyborczej 1990 r., następnie Unię Demokratyczną (od 13-14 maja 1991 r. powstałą ze zjednoczenia Unii Demokratycznej, Ruchu Obywatelskiego Akcji Demokratycznej oraz Forum Prawicy Demokratycznej), wreszcie Unię Wolności (powstałą 23 kwietnia 1994 r. na Kongresie Zjednoczeniowym w Warszawie z połączenia dwóch partii: Unii Demokratycznej i Kongresu Liberalno-Demokratycznego) (zob. Paszkiewicz, 2000, s. 133-137; taż, 2000, s. 142-149). Analiza dotyczyć jednak będzie obrazu wszystkich wymienionych powyżej podmiotów, w centrum zainteresowania leżą więc wszystkie formy organizacyjne tego względnie jednolitego środowiska (choć np. w drugiej połowie 1992 r. jej szeregi opuścili ludzie związani z Frakcją Prawicy Demokratycznej A. Halla, którzy utworzyli Partię Konserwatywną). Szerzej na temat UD oraz UW piszą: (Nyzio, 2014; Wincławska, 2010). 
nej w PiS po 2005 r. Ważne jest również, że członkostwo w UW miało miejsce w okresie schyłkowym dla ugrupowania, co było interpretowane jako przejaw silnych ideowych związków z partią. Ujawnienie faktu przeszłej przynależności do UW miało podważać wiarygodność A. Dudy jako osoby o niestabilnych przekonaniach politycznych. By to podkreślić eksponowano sprzeczność pomiędzy przynależnością do partii skrajnie krytycznej względem lustracji i traktującej dekomunizację jako rodzaj polowania na czarownice, a autoryzowaniem przez A. Dudę projektu radykalnej wersji lustracji w $2006 \mathrm{r}$. Siła ataku była tym intensywniejsza, że dziennikarze w pełni zdając sobie sprawę, jak UW była postrzegana w kręgach prawicowych zastosowali strategię odwrócenia argumentu. Z perspektywy liberalnego tygodnika naganna była nie tyle sama przynależność do UW, ile wyraźnie podkreślana zmienność poglądów. Jednocześnie ta sama przesłanka („A. Duda był członkiem UW”), w oczach wielu środowisk prawicowych tworzących PiS, a także będących poza PiS był cechą silnie dyskredytująca, jednak z innych, często niewypowiadanych powodów. Charakterystyczna była odpowiedź J. Kaczyńskiego, który pytany na konferencji prasowej o publikację wyjaśniał, że wiedział o fakcie dużo wcześniej. Jak mówił, informacja ta pojawiła się w deklaracji : „Tam jest taka rubryka, w której trzeba napisać, czy było się w jakiejś partii i w jakiej. On przecież nigdy tego nie ukrywał. Z mojego punktu widzenia to jest incydent” (Kaczyński, 2014). Co może wydawać się dziwne, odpowiedź J. Kaczyńskiego nie odnosiła się do sedna zarzutów formułowanych przez „Newsweek”. J. Kaczyński nie wskazywał więc na ewolucję poglądów kandydata czy pluralizm partii, w której szeregach miejsce znaleźć mogą ludzie o różnych poglądach, lecz odpowiedział zgodnie z niewyartykułowaną normą traktującą przynależność do UW jako cechę dyskredytującą.

W podobny sposób normę reprodukował również Minister Kultury i Dziedzictwa Narodowego Piotr Gliński deklarując podczas dyskusji parlamentarnej: „Byłem członkiem Unii Wolności [...] startowałem do Sejmu w wyborach, ale byłem członkiem frakcji ekologicznej zakładanej przez Ruch «Wolność i Pokój» [...] która była w bardzo ostrym konflikcie z ówczesnym liderem tej partii" (Sprawozdanie stenograficzne z 18 posiedzenia Sejmu, 2016). Wicepremier i minister reagował więc tak, jakby przynależność do UW była czymś, co wymaga usprawiedliwienia czy też zaprzeczania, nie będąc naturalnym elementem biografii polityka polskiego. Byłoby to tym bardziej zasadne, iż w Polsce, na co zwraca uwagę wielu badaczy, liczne transfery partyjne przez długi czas były zjawiskiem często spotykanym. Stąd w biografiach wielu polityków odnaleźć można przynajmniej kilka przeszłych filiacji partyjnych. Co jednak charakterystyczne, i w przypadku J. Kaczyńskiego i P. Glińskiego tłumaczenia nie były uzasadniane, nie dostarczano wyjaśnienia, dlaczego przynależność do UW należy kategoryzować jako „incydent” (J. Kaczyński), czy też skąd potrzeba podkreślania niegdysiejszego dystansu (P. Gliński).

Celem niniejszego tekstu jest ukazanie genealogii oraz analiza specyficznych treści budujących dyskredytującą normę, co pozwoli na lepsze zrozumienie implikowanych aspektów powyższych wypowiedzi. Zadanie to realizowane będzie poprzez analizę szczegółowych strategii budowania wizerunku środowiska UW i jej poprzedniczek: Ruchu Obywatelskiego Akcji Demokratycznej oraz Unii Demokratycznej podejmowanych przez ugrupowania prawicowe. Krytyka UW jako reguła prawicowej polityki tożsamości może być zbadana między innymi poprzez ustalenie treści dyskursu na temat partii, 
który był źródłem dyskredytujących argumentów. Jeśli przyjąć, że podstawą prawicowego samoopisu w Polsce lat 90. był antykomunizm oraz katolicyzm, a osią partyjnej rywalizacji podział postkomunistyczny (Grabowska, 2004), to szczególnie interesujące stają się te strategie, których celem było pozbawienie postsolidarnościowych UD i UW symbolicznego kapitału antykomunistycznego. Bazę empiryczną analizy stanowi dyskurs polityczny (wypowiedzi na łamach prasy, wywiady-rzeki, wystapienia programowe) oraz dyskurs dziennikarski (artykuły-opinie oraz felietony na łamach mediów blisko związanych z konkretnymi partiami politycznymi) z okresu 1989-2001. W świetle tez o częściowym paralelizmie między światem polityki i mediów zestawienie tych dwóch dyskursów wydaje się być uprawnione (Dobek-Ostrowska, 2011, s. 91; taż, 2012, s. 33-34). Wiele tytułów prasowych często bardzo otwarcie utożsamiało się z konkretnymi ugrupowaniami politycznymi (np. „Nasza Polska” wspierała środowiska polityczne związane z Janem Olszewskim i Antonim Macierewiczem), dziennikarze tych mediów byli niekiedy członkami partii, a politycy popieranych ugrupowań pojawiali się systematycznie na ich łamach. Uzupełnienie dyskursu politycznego o dyskurs dziennikarski pozwoli ponadto na pełniejszą rekonstrukcję niuansów argumentacji, przy pomocy której tworzono negatywny obraz środowiska Unii Wolności.

\section{Genealogia}

Korzeni stosunku prawicy do Unii Wolności szukać należy w okresie tzw. „wojny na górze", założycielskiego sporu w obozie solidarnościowym. I. Pańków porównuje ów okres do politycznej terapii szokowej stopniem radykalizmu przypominającej efekty planu L. Balcerowicza w sferze ekonomii (Pańków, 1998, s. 12). „Wojna na górze” była wydarzeniem znaczącym o tyle, o ile wymusiła samookreślenie się wielu ugrupowań, skłaniając je do pozycjonowania się $w$ ramach podziału lewica-prawica. Choć korzeni konfliktów związanych z tempem wychodzenia z komunizmu, pluralizacją obozu solidarnościowego, przyszłością NSZZ „Solidarność” oraz statusem ruchu komitetów obywatelskich należy szukać jeszcze w końcu roku 1988, same słowa o „wojnie na górze" wypowiedziane zostały przez L. Wałęsę jeszcze w maju 1990 r. podczas spotkania w Pucku, a następnie powtórzone na posiedzeniu Komitetu Obywatelskiego w Warszawie. Od tego momentu dochodzi do gwałtownego dzielenia się obozu solidarnościowego. Po jednej stronie stanęli tzw. „,pluraliści” zwolennicy wprowadzenia podziału partyjnego, po drugiej „elityści”, chcący utrzymać jedność „Solidarności” i ruchu komitetów obywatelskich jako organizacji stanowiących zaplecze dla rządu T. Mazowieckiego, co pozwoliłoby zabezpieczać proces wielowymiarowych reform (Pańków, 1998). Już wówczas oskarżano obóz T. Mazowieckiego o tendencje do monopolizacji władzy, zarzucano próby stworzenia monopartii, „Frontu Jedności Narodu”, „PZPR-Solidarności”, wzbudzającego podejrzenia „monolitu”, bliskości duchowej strony opozycyjnej naznaczanej stygmatem „lewicy” z rzeczywistą lewicą ,posttotalitarną” (Wałęsa, 1990a, s. 5; Wałęsa, 1990b, s. 2; Ławiński, 1990, s. 2). Z kolei orientacja na pluralizację obozu była ściśle związana z dążeniem L. Wałęsy do objęcia fotela prezydenckiego, a J. Kaczyńskiego do maksymalizacji wpływów nowopowstałego Porozumienia Centrum. Deklaracja ugrupowania z 12 maja 1990 r. podkreślała chęć przyspieszenia transformacji, a także wska- 
zywała na konieczność zmiany ówczesnego układu władzy, który miał konserwować „spadek po komunizmie” za pomocą polityki ,grubej kreski” (Deklaracja Porozumienia Centrum, 1990, s. 2). Dalszą konsekwencją „wojny na górze” była decyzja o zorganizowaniu bezpośrednich wyborów na urząd prezydenta, a także ogłoszenie decyzji o starcie przez L. Wałęsę, a następnie przez premiera T. Mazowieckiego. Stopniowo dochodziło również do podziałów w ramach Obywatelskiego Klubu Parlamentarnego, a także ruchu komitetów obywatelskich. Z kolei na poziomie partyjnym reakcją na powstanie PC było powołanie 16 lipca 1990 r. Ruchu Obywatelskiego-Akcji Demokratycznej, ugrupowania, które wspierało kandydaturę T. Mazowieckiego na prezydenta, a z którego w przyszłości wyłoniła się Unia Demokratyczna, a następnie Unia Wolności. Jak zauważył P. Śpiewak, wątki, toposy oraz schematy legitymizacyjne, które ukształtowały się w okresie „wojny na górze” podlegały w kolejnych latach przekształceniom, konkretyzacji, bądź specyfikacji, były jednak silnie zakorzenione w owym momencie fundacyjnym podziału solidarnościowego (Śpiewak, 2000, s. 90). Dyskurs charakteryzowała więc silna inercja, której wyrazem była powtarzalność wielu toposów, słów-kluczy, schematów interpretacyjnych, czy też argumentów krytycznych formułowanych wobec UD, a później UW w całym analizowanym okresie, a więc od ,wojny na górze” do opuszczenia parlamentu po wyborach 2001 r. O ile krytyka postkomunistycznego Sojuszu Lewicy Demokratycznej czerpała wiele z antykomunistycznego dyskursu opozycji politycznej sprzed 1989 r., o tyle krytyka środowiska późniejszej Unii Wolności swoje korzenie znajdowała właśnie w okresie „wojny na górze”. Ze względu jednak na rolę antykomunizmu dla budowania tożsamości prawicy oraz siłę podziału postkomunistycznego logika polaryzacji powodowała, że dominowała perspektywa „komunizacji” środowiska UD, a później UW². Wszystkie zachowania i decyzje polityczne środowiska, były ujmowane z perspektywy antykomunistycznej ramy dzielącej rzeczywistość polityczną na „my-oni”, zarówno na poziomie ontologicznym, jak i normatywnym. Podkreślić jednak należy, iż poszczególne ugrupowania prawicowe $\mathrm{w}$ różnym zakresie $\mathrm{z}$ owego zabiegu korzystały. $\mathrm{W}$ dodatku istniały również takie środowiska, które w okresie „wojny na górze” poparły T. Mazowieckiego, a w kolejnych latach konsekwentnie wysuwały pomysły stworzenia „obozu Polski posierpniowej" - prawicowej koalicji, która obejmowałaby również UW. Mowa przede wszystkim o A. Hallu, Partii Konserwatywnej i ugrupowaniach wywodzących się z tego środowiska politycznego (np. Koalicji Konserwatywnej czy Stronnictwa Konserwatywno-Ludowego).

\section{Strategie „komunizacji”}

Strategia „komunizacji” środowiska UW opierała się na systematycznym zawieszaniu różnicy poprzez podkreślanie tożsamości, a przynajmniej podobieństwa pomiędzy UW a SLD. W warunkach dominacji podziału postkomunistycznego, w którym

${ }^{2}$ D. Dabert pisząca o dyskursie prawicy zauważyła, że: „Poziom niechęci wobec postkomunistów jest stały. $Z$ drobnymi wahaniami. Największe negatywne emocje wywołują natomiast ugrupowania wyrosłe z ruchów opozycji demokratycznej i przedsierpniowej” (Dabert, 2003, s. 34). Podobnie I. Kamińska-Chmaj dostrzegała, iż na łamach wpływowego pisma prawicy - „Gazety Polskiej” ataki na UD czy UW były ostrzejsze, niż względem SLD (Kamińska-Szmaj, 2001, s. 80-81). 
tożsamość prawicy opierała się na antykomunizmie zabieg „komunizacji” wykluczał więc z grona partii dysponujących kapitałem symbolicznym wywodzącym się z mitu „Solidarności” i przesuwał ugrupowanie w stronę dyskredytującego bieguna (Lipiński, 2009). Zabieg „komunizacji” środowiska UW odnosił się do kilku wymiarów jej politycznego istnienia. Po pierwsze, na najbardziej generalnym poziomie dotyczył ustalania jej tożsamości politycznej oraz miejsca na scenie politycznej. Dyskursywnym tego wyrazem były zabiegi kategoryzacyjne, przypisujące partii (post)komunistyczną tożsamość. Po drugie, ważnym elementem była taka konstrukcja życiorysów i przeszłych politycznych zaangażowań liderów, która pozwalała dyskredytować roszczenia do opozycyjnego kapitału moralnego ${ }^{3}$. Wyrażało się to w konstruowaniu narracji historycznych, czy też eksponowaniu tych faktów, epizodów biografii czy aspektów działania, które pozwalały podważać prawo do odwołań do solidarnościowych korzeni. Po trzecie, identyfikowano idee, poglądy, ideologie przyświecające politycznej aktywności UW. Same działania, interesy leżące u ich podłoża, a także efekty działań podlegały negatywnej ocenie ze względu na związki z (post)komunizmem. W tej perspektywie UD, a później UW to partie, które jako sojusznicy SdRP, czy SLD ${ }^{4}$ wspomagały komunistów czy postkomunistów oraz wykazywały się tolerancją „,wobec komunizmu, postkomunizmu, półkomunizmu, dziedzictwa komunistycznego i wszystkiego, co się z tym łączy" (Kwieciński 1999, s. 18). Przedmiotem zainteresowania w niniejszym tekście będą dwie pierwsze strategie jako najbardziej spektakularne przejawy „komunizacji”. Nie oznacza to oczywiście jakiejkolwiek oceny co do znaczenia czy częstotliwości korzystania z którejkolwiek z trzech strategii dyskursywnych, płynące raczej $\mathrm{z}$ ograniczonych ram objętościowych tekstu.

\section{Przypisywanie lewicowej tożsamości}

Wiarygodność tezy o sojuszu z SLD uzyskiwana była poprzez szereg zabiegów kategoryzacyjnych, które miały zmniejszyć dystans pomiędzy obydwoma ugrupowaniami. Wielokrotnie opisywanej niechęci tego środowiska do podziału „lewica-prawica” (Chi-

${ }^{3}$ Pojęcie kapitału moralnego stosuję za Johnem Kanem. Kapitał moralny jest rodzajem moralnego prestiżu podmiotu zbiorowego, bądź indywidualnego, wykorzystywanego dla realizacji określonych celów. Określenie „opozycyjny” odnosi się do zaangażowania w działania opozycyjne w okresie PRL skierowane przeciwko niedemokratycznej władzy. Jak zauważa J. Kane wrażliwość tej formy kapitału wynika z faktu, że jego istnienie jest wynikiem ludzkich sądów moralnych i jako takie zależy od społecznej percepcji. Oznacza to, że zainteresowane podmioty polityczne oraz ich oponenci poprzez wpływanie na percepcję za pośrednictwem dyskursu mogą wzmacniać, osłabiać, bądź pozbawiać kapitału moralnego (Kane, 2004, s. 7).

${ }^{4}$ Mniej lub bardziej bezpośrednie stwierdzenia o sojuszu części sił solidarnościowych oraz postkomunistów znaleźć można w szeregu wypowiedzi. J. Parys mówił o „siłach postkomunistycznych i chroniących je grupach dawnej opozycji” (Cyt. za: Szemplińska, 1992, s. 21). ZChN oskarżał „posłów lewicy postkomunistycznej i ich sojuszników z lewicy solidarnościowej" o powodowanie kryzysów politycznych (Oświadczenie ZChN, 1991, s. 3). S. Niesiołowski pisał o „części dawnej demokratycznej opozycji”, która zaakceptowała zmianę tożsamości komunistów i uznała ich za wiarygodnych partnerów politycznych (Niesiołowski, 1994, s. 5). Jan Parys wyjaśniał z kolei: „Komunizm odrodził się szybko, bo miał dobre zaplecze, dobre przyczółki i nieświadomych sojuszników. Tu potężną winę ponosi UD [...]" (J. Parys) (Cyt. za: Gargas, 1993, s. 3). 
miak, 2010, s. 141-149) już od czasu tzw. wojny na górze odpowiadały strategie narzucające etykiety czy wymuszające przyjęcie tożsamości (Dunin, Kraśko, 1991, s. 201-203; Pańków 1998, s. 10-11), o tyle ważne, iż „lewicowość” była traktowana jako „miara skomunizowania" (Pankowski 1997, s. 96-98). Owej tożsamości zdecydowanie odmawiano cech prawicowych (Parys, 1994b, s. 6; Załuska, 1994, s. 3), zarzucając również brak antykomunistycznego nastawienia ${ }^{5}$, traktowanego rzekomo w tym środowisku jako „epitet, wstydliwa przypadłość, niegodna kulturalnego, bywałego człowieka” (Kwieciński, 1999, s. 18). Obecny w tym środowisku sprzeciw wobec sytuowania się w ramach podziału „lewica-prawica” był uznawany za wyraz dążeń do zawłaszczenia całej sceny politycznej, bądź ukrywania swojej prawdziwej ideologii, co potwierdzało tylko fakt, iż była ona zła, nieprawomyślna i zasługująca na potępienie (zob. np. Wierzbicki, 1989, s. 8-9). Retoryka „wojny na górze” stwarzała więc rodzaj podwójnego szantażu. Przypisywanie etykiety lewicy przez ugrupowania pozycjonujące się jako „,prawica” było deprecjonująca etykietą ujawniającą ideowe powinowactwo. Jej odrzucanie zaś dawało asumpt do podejrzeń o maskowanie swojej prawdziwej tożsamości.

Ogólne określenie lewicy było często uzupełniane o wskazujące rodowód oraz nastawienia ideowe przymiotniki. W opisie środowiska UD czy UW posługiwano się terminami „opozycyjna lewica”, „solidarnościowa lewica”, „lewica laicka”, która pozostawała w sojuszu z ,lewicą katolicką”, ugrupowanie „lewicowo-liberalne”, ,socjalliberalne”, a nawet „Nowa Lewica” (Krzaklewski, 1996, s. 13; Niesiołowski, 1990, s. 1; Siergiejczyk, 1996, s. 3; Kaczyński, 1996, s. 4; Kaczyński, 1994, s. 5; Jakucki, 1997, s. 1; Kwieciński, 1994, s. 16). Szczególnie dyskredytująca była kategoria „udecji”, będąca derywatem nawiązującym do nazwy komunistycznej instytucji. Kategoria lewicy, obecna we wszelkich nominacjach tego środowiska już na poziomie językowym była oznaką bliskości czy nawet tożsamości UW i przyznających się do lewicowości postkomunistów.

Innym jeszcze sposobem dyskredytacji środowiska było przypisywanie, nie tyle lewicowej, ale wręcz komunistycznej tożsamości. Definicja komunizmu, będąca bazą dla takiego zabiegu miała charakter silnie perswazyjny, obejmując wszystkie te składniki, które pozwalały na deprecjonowanie, niezależnie od stopnia ich związków z ustalonym znaczeniem terminu. Pisano na przykład, iż UW posiada ,typowo komunistyczną cechę: niezdolność do dzielenia się czymkolwiek (np. wpływami) z kimkolwiek" (Wierzbicki, 1993, s. 2). Partii przypisywano rozumienie demokracji jako ustroju, w którym rządzą demobilizujące społeczeństwo elity oraz tendencję do wprowadzenia demokracji sterowanej, „będącej pochodną demokracji socjalistycznej” (Niesiołowski, 1990, s. 1). Zasadnicza intencja wszelkich dążeń „lewicy laickiej” oraz „lewicy katolickiej” polegała na dążeniu do wyeliminowania prawicy i stworzenia układu oligarchicznego oraz demokracji fasadowej wraz z SLD. Efektem miał być istniejący w Polsce układ oligarchiczny, a rzekoma dwubiegunowość, w rzeczywistości wyparta została przez jednobiegunowość (Jakucki, 1999, s. 9; Wierzbicki, 1995, s. 16; Lipiński, 1996, s. 8). W pierwszej opcji, UD/UW dążyła do władzy, korzystając z pomocy komunistów, w drugiej opcji, dąży-

${ }^{5}$ Zdaniem P. Łączkowskiego z Partii Chrześcijańskich Demokratów, UW nie mogła zostać uznana za ugrupowanie „wyraźnie antykomunistyczne” (cyt. za: Zdort, Reszka, 1996, s. 4).

6 Określaną obraźliwie jako „katolewica”. Jak wyjaśnia J. M. Jackowski, byli to „postępowi katolicy często zorganizowani w KIK-ach” (Jackowski, 1993, s. 81). 
ła do władzy wraz z komunistami, w trzeciej, wspomagała komunistów w utrzymaniu dziedzictwa PRL, prowadziła bowiem politykę zakładająca, iż ,układ postpeerelowski jest nienaruszalny" (Kaczyński, 2000, s. 16). Z tego wywodzono dalsze wnioski, które naturalizowały wzajemne związki środowiska UW z postkomunistami, sprowadzając tezy o ich istnieniu do twierdzeń o oczywistościach, pewnikach, które nie ulegają wątpliwości, wreszcie niepoddawanych refleksji punktach wyjścia do dalszych rozważań7. To prowadziło do ześlizgiwania się dyskursu w stronę ataków, które po prostu zrównywały UW z postkomunistami, bądź komunistami. Najbardziej radykalne stwierdzenia formułowane w obrębie omawianego stanowiska mówiły o UD, czy później UW, jako partii postkomunistycznej (Wawrzynowski, 1997, s. 9; Kaim, 1993, s. 5), traktowały SLD i UW, jako partie „skupiające dwie odmiany komunistów” (Jakucki, 1999, s. 1), czy jako „spadkobierców stalinizmu” (Echolette, 2000, s. 14). UW to formacja zależna, służebna, „niejako wobec komunistów pomocnicza”, „ozdobnik” SLD (W. K., 1999, s. 1; Glapiński, 1994, s. 4). Zawieszanie różnicy pomiędzy SLD i UW umożliwiała również charakterystyczna klisza „różowych”, jako sojuszników „,zerwonych”, którą często się posługiwano, a która odnosiła się właśnie do środowiska UW (Kwiatek, 1997, s. 3; Wrzodak, 1997, s. 4; Chrzanowski, 1999, s. 19; Jackowski, 1993, s. 83; Chrzanowski, 1997, s. 434-435). UW to po prostu „różowi”, będący w ścisłych związkach z komunistami. W perspektywie prawicowej środowisko „różowych” nie tworzyło wyraźnej alternatywy dla postkomunistów, było ono nie tylko zorientowane na współdziałanie z SLD, nie tylko dążyło do współrządzenia z nimi, ale co więcej, przyczyniało się do rehabilitacji komunistów (Parys, 1994a, s. 5; Parys, 1994b, s. 6; Niesiołowski, 2000, s. 7).

\section{Pozbawianie opozycyjnego kapitału moralnego}

Deprecjonowanie poprzez wskazywanie niechlubnej, kompromitującej przeszłości, tak istotne w odniesieniu do postkomunistycznego SLD (zob. Lipiński, 2007), znajdowało zastosowanie również w odniesieniu do UW, mimo opozycyjnych zaangażowań liderów i szeregowych członków partii. Uznanie znaczenia działalności opozycyjnej środowiska późniejszej UW, której początki datowano na rok 1956 było rzadkie (Siergiejczyk, 1996, s. 3) ${ }^{8}$. Opozycja, którą tworzyło środowisko UW to opozycja z założenia gorsza, bo „wewnątrzsystemowa” (Kaczyński, Bichniewicz, Rudnicki, 1993, s. 11; Chrzanowski, 2000, s. 12), czy „koncesjonowana (KIK, KOR)”, „liberalne skrzydło PZPR” (Zawisza, 1996, s. 7), czy inaczej, „część dawnych aktywistów PZPR”.

${ }^{7}$ Strategię naturalizacji, jako jeden z efektów ideologii błyskotliwie omawia T. Eagleton (Eagleton, 1991, s. 58-61). Jej wykorzystanie sygnalizowały następujące stwierdzenia: „Wspólna droga z byłymi PZPR-owcami z natury rzeczy bardziej odpowiada lewicy, niż ugrupowaniom o nielewicowych zapatrywaniach”; ,Z punktu widzenia elity PZPR naturalnym kandydatem do roli takiego koła ratunkowego jest opozycyjna lewica" (Kaczyński, 1989, s. 3; Pawłowski, Węgiełek, 1990, s. 7).

8 Przy takim stanowisku konsekwentnie obstawał J. Kaczyński, choć i on zwracał uwagę na negatywne konsekwencje minimalistycznych form przeszłej działalności opozycyjnej, charakterystycznych np. dla ruchu „Znak”: nadmierne obawy przed komunistami sięgające jeszcze okresu III Rzeczpospolitej czy niechęć do jednoznacznych, dekomunizacyjnych działań (zob. Kaczyński, 1996, s. 4).

9 Najbardziej radykalne, przesycone antysemityzmem i inspirowane tekstem W. Jedlickiego (zob. W. Jedlicki, Klub Krzywego Koła, Warszawa 1989, s. 17-60 [rozdz. pt. „Chamy i Żydy”]) sformułowa- 
Pozbawianie opozycyjnego kapitału moralnego, budowanego jeszcze w okresie Komitetu Obrony Robotników, dokonywało się najczęściej trojako. Po pierwsze, w rozważaniach na temat historii środowiska podkreślano komunistyczną przeszłość, , ukąszenie heglowskie", któremu uległo wielu liderów partii ${ }^{10}$, wskazywano na rewizjonistyczne, socjalistyczne czy trockistowskie korzenie ${ }^{11}$, chętnie przywoływano stalinowskie zaangażowania z przeszłości, a także ustawicznie podkreślano fakt przynależności do PZPR (Zawisza, 1996, s. 8; Jakucki, 1999, s. 9) ${ }^{12}$. UD miała być „nieliczną, zahartowaną w bojach grupą ludzi, którzy wyszli z tradycji komunistycznej, leninowskiej, trockistowskiej, bądź rewizjonistycznej. Wywodzą się na ogół z rodzin działaczy przedwojennej Komunistycznej Partii Polski, organizacji agenturalnej" (Wierzbicki, 1993, s. 2) ${ }^{13}$. Zetknięcie z systemem zawsze oznaczało degradację i natychmiast sytuowało po stronie zła, a oczywistość normatywnej kwalifikacji była wzmacniana tezą o trwałości takiej degradacji. Stąd eksponowanie genealogii nabierało wielkiego znaczenia, bo wskazywało na intencje, motywacje oraz schematy bieżących działań, które na zawsze miały być skażone piętnem układu komunistycznego. Związek z komunizmem podlegał więc esencjalizacji, będąc wyobrażanym jako rodzaj skażenia, które na trwale przekształca istotę indywidualnej i zbiorowej tożsamości.

Po wtóre, degradacja przeszłości opozycyjnej środowiska UW dokonywała się również poprzez przypisywanie działalności opozycyjnej tego środowiska aspołecznych, egoistycznych intencji oraz błędnych i antynarodowych kalkulacji politycznych. Intencje owe wiązały się przede wszystkim z dążnością do zaspokojenia grupowych interesów o charakterze politycznym czy ekonomicznym (Jackowski, 1993, s. 44; Olszewski, Polak-Pałkiewicz, 1997, s. 162, 189) ${ }^{14}$. Wariantem tego poglądu była teza o nie tyle

nia genealogię UW wywodzące z tzw. frakcji ,żydów” w PZPR, która dążyć miała do historycznego kompromisu $\mathrm{z}$ „chamami” partyjnymi. Z wersją tą lansowaną przez S. Michalkiewicza polemizowali publicyści „Myśli Polskiej” i „Naszej Polski”, którzy twierdzili, że całe kierownictwo SLD również wywodzi się z frakcji „żydów” (zob. Siergiejczyk, 1997, s. 9; tenże, 1997, s. 8).

10 „Scedowanie na grupę ludzi niegdyś «ukąszonych przez Hegla» niemal całej odpowiedzialności za kraj było straszliwym błędem, dzięki któremu powstały mechanizmy zawłaszczenia gospodarki i ludzkich umysłów przez postkomunistów" (Krzaklewski, 2000, s. 3).

${ }^{11}$ Charakterystyczny zabieg stosował M. Krzaklewski, dokonując rozróżnienia pomiędzy „lewicą laicką a opozycją katolicką", podważając tym samym opozycyjny status tej pierwszej (Krzaklewski, Łętowski, Zaremba, 1997, s. 26).

${ }_{12}$ R. Bender pisał: „Przecież wielu obecnych posłów i senatorów z UD to dawni towarzysze, byli członkowie PZPR" (Trzy pytania..., 1991, s. 2). Szczegółowo komunistyczne filiacje organizacyjne B. Geremka, J. Kuronia, J. Osiatyńskiego, M. Święcickiego czy L. Balcerowicza wskazywał (Sergiejczyk, 1998, s. 5). Odnośnie T. Mazowieckiego pisał: „wprawdzie do PZPR nie należał, ale swoją karierę rozpoczął od publikowania tekstów szkalujących biskupa Kaczmarka w czasie jego procesu w 1953 roku, by później, przez kilka kadencji zasiadać w PRL-owskim Sejmie". Prawa do odwoływania się do solidarnościowej, opozycyjnej tradycji poprzez wykazywanie przeszłych komunistycznych zaangażowań odmawiał również Jakucki $(1997$, s. 1). Podobnej analizy przeszłości w odniesieniu do L. Balcerowicza dokonywał Sakiewicz (1995, s. 10-11).

13 O „formacji KPP”, z której wywodzić się miała i która wpływać miała na UW mówili też: J. Kaczyński i J. Olszewski (zob. Kaczyński, Bichniewicz, Rudnicki, 1993, s. 20; Olszewski, PolakPałkiewicz, 1997, s. 192-193).

${ }^{14}$ A. Macierewicz mówił o konsekwentnej realizacji przez środowisko „korowskie” jednej linii - zdobycia władzy (zob. Macierewicz, 1993, s. 198). P. Bączek pisał, iż mimo ewolucji poglądów w tej grupie „cel pozostawał zawsze ten sam - zdobycie władzy” (Bączek, 1994, s. 5). Znaczące były 
złych intencjach KOR, a później doradców, intelektualistów działających w „Solidarności”, ile negatywnych, niezamierzonych efektach ich działań. Nawet, jeśli intencje były nienaganne, działania prowadziły do niekorzystnych dla społeczeństwa skutków. Aspołeczność wynikała więc z mechanizmów, działających poza obszarem indywidualnych intencji oraz wpływów i była pochodną manipulacyjnej aktywności władzy ${ }^{15}$. Mniej socjologizujące, a bardziej psychologizujące wyjaśnienie eksponowało rolę indywidualnych ambicji politycznych, dążenie do osiagnięcia eksponowanych stanowisk, zmonopolizowania władzy, zmonopolizowania dziedzictwa np.: zawłaszczenia „Solidarności” przez lewicę laicką. Ponadto podkreślano, iż orientacja na finlandyzację Polski, rozmowy z reformatorskim skrzydłem PZPR, porozumienie z nim i współrządzenie krajem w najlepszym razie były błędem politycznym, niepotrzebnym ograniczaniem horyzontu działań kontestatorskich (Kaczyński, Bichniewicz, Rudnicki, 1993, s. 11), a w najgorszym naruszały fundamentalny cel opozycji, którym miała być niepodległość kraju ${ }^{16}$.

Po trzecie, podejrzliwość względem minionych działań dysydenckich budowano poprzez obniżanie rangi tego typu aktywności. Wskazywano, iż działania te nie wymagały odwagi i bohaterstwa. Zgodnie z populistyczną strategią dodawano, iż jeśli w ogóle można mówić o rzeczywistym niebezpieczeństwie, to dotyczyło ono „szeregowych działaczy włączających się dopiero co do ruchu, albo go wspierających" (Olszewski, Polak-Pałkiewicz, 1997, s. 197, 198). Podkreślano, że solidarność środowiskowa, kontakty zagraniczne z wspierającym opozycję lewicową, socjalistyczną czy liberalną Zachodem, wreszcie nacisk ludzi o znanych nazwiskach i dużej reputacji ograniczały możliwość represji (Jackowski, 1993, s. 85; Olszewski, Polak-Pałkiewicz, 1997, s. 197-198), a fundusze oraz polityka władz komunistycznych, wspierających lewicową opozycję dawała im przewagę nad ludźmi o prawicowych poglądach (Olszewski, Polak-Pałkiewicz, 1997, s. 194; Macierewicz, 1993, s. 194-196) ${ }^{17}$. Że ludzie KOR mieli status opozycji uprzywilejowanej, chronionej przez władzę. Skrajną wersją tego poglądu było przekonanie, iż opozycja została po prostu stworzona przez władzę, po to by zapewnić sobie przewidywalnego partnera do rozmów, a jednocześnie kanalizować napięcia społeczne, obecne

również stwierdzenia M. Krzaklewskiego, dotyczące środowiska KOR, iż nie chciało ono bronić aresztowanego K. Świtonia, znanego z prawicowych poglądów założyciela pierwszych Wolnych Związków Zawodowych na Śląsku, „bo nie był «ich»” (Krzaklewski, Łętowski, Zaremba, 1997, s. 26). Z tym poglądem polemizował A. Michnik, wskazując na szereg oświadczeń KOR, dokumentujących wysiłki mające na celu obronę opozycjonisty (Michnik, 1997, s. 1; Dańko, Michnik, 1997, s. 5).

15 O doradcach „Solidarności” oraz ludziach związanych z KOR, wywierających silny wpływ na związek mówił J. Olszewski: „Nie chciałbym zarzucać ludziom, którzy wówczas brali w tym udział, że robili to z całkowitym cynizmem, zakładając, że robią na tym osobistą karierę. Być może w tym momencie nie przychodziło im to do głowy i uważali, że z punktu widzenia realnych możliwości to jest jedyne usprawiedliwione działanie”, jednak te działania ludzi opozycji władzy się ,opłaciły” (Olszewski, Polak-Pałkiewicz, 1997, s. 209).

16 J. Olszewski mówił o ,reformowaniu PRL-u i współpracy z ugrupowaniami wewnątrzpartyjnymi”, jako celu działań lewicowej opozycji (zob. Olszewski, Polak-Pałkiewicz, 1997, s. 199).

17 Jak mówił M. Krzaklewski: „Pamiętajmy, że od pewnego momentu opozycja korowska była nieco łagodniej traktowana przez władze, niż pozostała część opozycji, choćby KPN czy Świtoń. Jak wynika z pewnych źródeł ONZ, KOR mógł liczyć nawet na stosunkowo niewielką pomoc materialną. [...] KOR był dla komunistycznego rządu listkiem figowym wobec zachodnich rządów. Łagodniejsze traktowanie go przez rząd komunistyczny było spłacane zachodnimi kredytami zaciąganymi przez Gierka" (Krzaklewski, Łętowski, Zaremba, 1997, s. 73). 
W reżimie niedemokratycznym ${ }^{18}$, co miało być efektem szerszej strategii komunistów, swoje korzenie znajdującej w Moskwie ${ }^{19}$.

Wszystkie te wątki, choć obecne w formie rozproszonej w wypowiedziach wielu polityków prawicy, współwystępowały jedynie na najdalej wysuniętym stanowisku w ramach omawianego bieguna, tworząc rodzaj opowieści, swoisty schemat historiozoficzny, wyjaśniający meandry najnowszych dziejów Polski i identyfikujący przyczyny aktualnego zła. Narracja o najnowszej historii Polski to opowieść linearna i spójna dzięki ciągłości tożsamości oraz zbieżności interesów dwóch stron kontraktu Okragłego Stołu - kontraktu decydującego o kształcie III Rzeczypospolitej, umowy, która zaprogramowała i określiła, jeśli nie dokładny przebieg (Olszewski, 1993, s. 9), to z pewnością warunki brzegowe transformacji w Polsce (Macierewicz, 1993, s. 197). W tej opowieści polski ruch oporu przeciwko rządom komunistycznym obejmował dwa nurty, jeden prawowity - niepodległościowy, bliski narodowi i wartościom przezeń wyznawanym, drugi - „dysydencki”, tworzony przez ludzi rozczarowanych do systemu komunistycznego, ale pochodzący z jego wnętrza. Oba nurty współdziałały w obliczu wspólnego wroga, lecz od początku istniało, wprawdzie tuszowane, ale jednak poczucie różnicy ${ }^{20}$ i większej siły pierwszego nurtu wynikające ze wsparcia własnych środowisk, środków masowego przekazu z zagranicy, lepszego do nich dostępu, lepszej organizacji (Kaczyński, Bichniewicz, Rudnicki, 1993, s. 11). Owo poczucie różnicy wynikało z odmiennych aspiracji oraz poglądów na cel, w jakim zmierzać winna działalność opozycyjna. W pierwszym przypadku była to działalność wynikająca $\mathrm{z}$ indywidualnych czy środowiskowych aspiracji politycznych, zorientowana na reformowanie i liberalizację systemu, w drugim, dążność do wyrażenia pragnień społeczeństwa - narodu, której celem ostatecznym miało być „obalenie komunizmu” (Olszewski, 1993, s. 8). Ów spór co do intencji i celów widoczny już w okresie KOR, znacznie mocniej w okresie „Solidarności” 1980-1981, będąc stłumiony przez stan wojenny i okres działalności podziemnej, z całą mocą ujawnił się przy Okragłym Stole. Jego strony tworzyły grupy sobie bliskie, tworzące układ spleciony wzajemnymi zależnościami: genealogicznymi, ideowymi, agenturalnymi, finansowymi i politycznymi. Do rozwoju owego układu, obecnego

${ }^{18}$ A. Macierewicz mówił o tym w sposób następujący: ,Władcy tego systemu [PRL - A.L.] bardzo dbali o to, żeby ruch opozycyjny ująć w karby przez siebie sterowanych i przygotowywanych elit”, dalej mówiąc o owych władcach: „Rzecz w tym, czy ustąpiliby przed siłami przez siebie wykreowanymi, na warunkach, które im narzucili (i które te siły zgodziły się po dziś dzień respektować, że wspomnę choćby sprawę majątku PZPR), czy też musieliby ustępować przed siłami autentycznymi" (Macierewicz, 1993, s. 196-197). W ramach takiej optyki można było nawet formułować kuriozalne tezy, iż lewica w 1993 r. ,wygrała wybory, bo miała sojuszników w ludziach, którzy co najmniej od 1976 r. udawali opozycję [kursywa - A.L.], po to, by przejąwszy władzę roztoczyć nad «czerwonymi» parasol ochronny" (Kwiatek, 1997, s. 3).

${ }^{19}$ Globalna strategia transformacji przygotowywana przez KGB i GRU zakładała, iż „władza spoczywa w rękach wyselekcjonowanej, niekomunistycznej, liberalno-lewicowej elity, życzliwej i przychylnej wobec imperialnych dążeń Rosji i interesów krajowych komunistów” (Glapiński, 1996, s. 11).

${ }^{20}$ Wyrażające się już na poziomie językowym. Jak mówił J. Olszewski: „Odmiennie reagowaliśmy na pewne pojęcia. Używanie słowa «niepodległość», pomimo, że była ona wówczas mało realna, było jednak dla nas czymś naturalnym. To był ten ostateczny, najistotniejszy cel. Słowo «naród» odnosiło się do bardzo konkretnej rzeczywistości. Grupa Kuronia i Michnika takich słów nie używała. Dla nich były to określenia, jakich «ludzie z towarzystwa» nie używają" (Olszewski, Polak-Pałkiewicz, 1997, s. 163). 
właściwie od początku istnienia opozycji dysydenckiej, doszło w toku lat 80., kiedy to władza poprzez różnego rodzaju mechanizmy, w tym działalność agenturalną, tworzyła opozycję lewicowa, zaś ta ostatnia monopolizowała władzę w strukturach podziemnych, a później oficjalnych (Kern, 1997, s. 4). Okragły Stół to kontrakt, który miał zapewnić bezpieczeństwo i korzyści stronie komunistycznej, zachowanie dominujących wpływów w państwie i gospodarce. Podobnym celom miała również służyć polityka „grubej kreski” rządu T. Mazowieckiego, zabezpieczająca byłych działaczy PZPR przed rozliczeniami, zachowująca ich wpływy w kluczowych strukturach polityczno-ekonomicznych oraz zezwalająca na uwłaszczenie nomenklatury ${ }^{21}$. Późniejszy dystans tego środowiska do tworzenia partii politycznych w pierwszym okresie po 1989 r., do posługiwania się etosem „Solidarności” jako szyldem, pod którym zbierać się miała cała strona postsolidarnościowa, traktowane były właśnie jako wyraz układu z komunistami, dążenia do zawłaszczenia całej sfery politycznej oraz uczynienia z demokracji fasady, w ramach której rywalizować ze sobą miały pozornie tylko alternatywne siły (Michalkiewicz, 1996, s. 4; Michalkiewicz, 1997, s. 3; Kaczyński, Bichniewicz, Rudnicki, 1993, s. 29-31; Kaczyński, 1994, s. 104).

Równie koherentna narracja jak ta dotychczas przedstawiona rzadko była adresowana do szerszej publiczności, rzadko też wykraczała poza łamy prasy prawicowej czy sale skupiające zwolenników partii radykalnie dekomunizacyjnych, czy niepodległościowych (np. Ruch Trzeciej Rzeczpospolitej, Ruch Odbudowy Polski). Swój najbardziej bodaj spójny wyraz znalazła w głośnej wypowiedzi członka Ruchu Odbudowy Polski Z. Wrzodaka w 20. rocznicę Czerwca '76, kiedy to porównał KOR do „różowych hien”, które konsekwentnie realizowały swój interes polityczny, kosztem robotników (Wrzodak, 1997, s. 4). Reakcja, z jaką spotkała się ta wypowiedź nie zawsze była równie jednoznaczna jak Z. Romaszewskiego, który wskazywał na konieczność ostrego rozdzielenia oceny KOR od działalności wielu ludzi tego środowiska w okresie późniejszym (Romaszewski, 1995, s. 5). Przywódcy dwóch wpływowych ugrupowań prawicy: AWS i ROP dalecy byli od równie jednoznacznych stwierdzeń, wskazując raczej na obiektywne efekty działań, które potwierdzać miały przekonania Z. Wrzodaka, niezależnie od indywidualnych motywacji ludzi KOR, dopuszczając możliwość snucia takich spekulacji, ze względu na to, że rola „lewicy laickiej w różnych działaniach obozu sierpniowego" nie została wyjaśniona, czy wreszcie neutralizując moc wypowiedzi poprzez fakt jej pochodzenia ze środowiska robotniczego, a więc wspólnoty niewrażliwej na niuanse, posługującej się kodem ograniczonym (Krzaklewski, 1996, s. 13; Krzaklewski, Łętowski, Zaremba, 1997, s. 217; Olszewski, Polak-Pałkiewicz, 1997, s. 209).

W praktyce analizowana narracja była traktowana jako ważny zasób nie tylko w tym sensie, że komponenty dyskursywne, z których się składała były wykorzystywane w sposób swobodny przez wielu polityków prawicy. Ich częściowe wykorzystanie pozwalało

${ }^{21}$ Zwięźle wyrażał to J. Olszewski, wyjaśniając przyczyny sukcesu postkomunistów w 1993 r.: „Prawdziwymi autorami tego sukcesu są partie odpowiedzialne za dotychczasowy charakter tzw. transformacji ustrojowej w Polsce, a więc przede wszystkim Unia Demokratyczna i KLD. To im komuniści zawdzięczają zachowanie dominujących wpływów w strukturach państwa i najważniejszych sferach gospodarki. «Gruba kreska» zwolniła ich od odpowiedzialności za czterdzieści parę lat PRL i pozwoliła jednocześnie obciążyć hipoteką wszystkich trudności ostatnich czterech lat Solidarność" (Olszewski, 1993, s. 3). 
zachować, bądź przyciągać twardy, radykalnie myślący elektorat prawicowy, a jednocześnie poszerzać apel wyborczy tak, by trafiał on do grup bardziej umiarkowanych. Użycie tylko pewnych komponentów, chroniło przed zarzutami o radykalizm, a jednocześnie pozwalało ewokować treści znane radykalnym wyborcom prawicy, a więc czynić aluzje do znanych schematów interpretacji, słów o uzgodnionych znaczeniach czy linii argumentacyjnych. W latach 90 . mniej lub bardziej zdecydowana krytyka UW była dominującą postawą na prawicy. Skrajna krytyka UW była cechą charakterystyczną Ruchu Odbudowy Polski oraz Akcji Wyborczej Solidarność, dwóch największych podmiotów prawicowych drugiej połowy lat 90 . Zjawisko to dostrzegał P. Zaremba: „Zespół na Rzecz Programu AWS z Adamem Słomką i Janem Marią Jackowskim opiera na krytyce nadmiernych unijnych wpływów, także i programowych, bez mała całą swą tożsamość. Zresztą znaczna część Akcji - i ta związkowa, i ta narodowo-katolicka, i ta najbardziej antykomunistyczna - jest mocno przywiązana do takiej wizji rzeczywistości" (Zaremba, 1998, s. 6). Współcześnie skrajna krytyka środowiska UW i jego poszczególnych przedstawicieli jest na prawicy normą na tyle oczywista, że bardzo często sama nazwa partii, populistyczne określenia jej inteligencko-elitystycznego charakteru (np. salon) bądź derywaty wywodzące się od nazwisk sympatyków partii (np. michnikowszczyzna) służą celom etykietującym, bez konieczności przywoływania szczegółowej argumentacji.

\section{Bibliografia}

Bączek P. (1994), Oszustwo stulecia, „Najwyższy Czas” 5 lutego, nr 6.

Bogucka T. (1997), Na dwoje Akcja wróżyła, „Gazeta Wyborcza” 8-9 marca, nr 57.

Chimiak K. (2010), ROAD. Polityka czasu przełomu. Ruch Obywatelski-Akcja Demokratyczna, Fundacja Lorga, Płock 2010

Chrzanowski W. (1997), Pół wieku polityki czyli rzecz o obronie czynnej, Ad Astra, Warszawa.

Chrzanowski W. (2000), Przemówienie na Zjeździe Założycielskim ZChN w dniu 28 X 1989 r., „Sprawa Polska", nr 3.

Chrzanowski W. (1999), Legenda okragłego stołu - wywiad, „Życie” 11 maja, nr 108.

Dabert D. (2003), Mowa kontrolowana. Szkice o języku publicznym w Polsce po 1989 roku, Wydawnictwo „Bonami”, Poznań.

Dańko I., Michnik A. (1997), Tak było (w przybliżeniu), „Gazeta Wyborcza” 15 listopada, nr 215.

Deklaracja Porozumienia Centrum (1990), „Tygodnik Solidarność” 13 maja, nr 20.

Dobek-Ostrowska B. (2011), Polski system medialny na rozdrożu. Media w polityce, polityka w mediach, Wydawnictwo Uniwersytetu Wrocławskiego, Wrocław.

Dobek-Ostrowska B. (2012), Italianization (or Mediterraneanization) of the Polish Media System? Reality and Perspective, w: Comparing Media Systems Beyond the Western World, red. D. C. Hallin, P. Mancini, Cambridge University Press, Cambridge.

Domosławski A. (1997), Przeciw „,bolszewikom”. Z dziejów polskiej prawicy 1989-1997 (część 6 - ostatnia), „Gazeta Wyborcza” 16 września, nr 216.

Dunin K., Kraśko N. (2010), Nieprawica, czyli o tym czy możliwa jest w Polsce lewica, w: Cudze problemy. O ważności tego, co nieważne. Analiza dyskursu publicznego w Polsce, red. M. Czyżewski, K. Dunin, A. Piotrowski, Wydawnictwa Akademickie i Profesjonalne, Warszawa.

Eagleton T. (1991), Ideology. An introduction, Verso, London-New York. 
E.S. (1998), Izolować lewice, „Głos” 7 lipca, nr 127.

Echolette A. (2000), Komunistyczni bracia syjamscy, „Nasza Polska” 14 czerwca, nr 24.

Gargas A. (1993), Między nami, liderami, „Gazeta Polska” 30 listopada, nr 11.

Glapiński A. (1994), Jaka Polska? Między suwerennościq a serwilizmem, „Tygodnik Solidarność” 29 grudnia, $n r 48$.

Glapiński A. (1996), Ukryta wtadza, „Gazeta Polska” 15 lutego, nr 6.

Grabowska M., Podziat postkomunistyczny. Społeczne podstawy polityki w Polsce po 1989 roku, Warszawa 2004.

Jackowski J. M. (1993), Bitwa o Polske, Ad Astra, Warszawa.

Jakucki P. (1996), Faryzeusze, „Nasza Polska” 13 czerwca, nr 24.

Jakucki P. (1997), Rocznica zdrady, „Nasza Polska” 12 lutego, nr 7.

Jakucki P. (1997), Spadkobiercy PZPR, „Nasza Polska” 5 lutego, nr 6.

Jakucki P. (1999), Czerwoni demagodzy w ataku, „Nasza Polska” 12 maja, nr 19.

Jakucki P. (1999), Recydywiści z UW, „Nasza Polska” 27 grudnia, nr 43.

Kaczyński J. (1994), Nowa Polska czy jeszcze stara?, w: T. Torańska, My, Wydawnictwo „Most”, Warszawa.

Kaczyński J. (1994), Pierwsze przykazanie: Jednoczmy się, „Gazeta Polska” 24 marca, nr 12.

Kaczyński J. (1996), Tolerowana agentura - wywiad, „Nowe Państwo” 26 stycznia, nr 4.

Kaczyński J., Bichniewicz M., Rudnicki P. M. (1993), Czas na zmiany, Editions Spotkania, Warszawa.

Kaczyński J. (1989), Sojusz madrych, „Tygodnik Solidarność” 15 grudnia, nr 28.

Kaczyński J. (2000), Trudno iść razem, „Życie” 30 maja, nr 125.

Kaczyński o przeszłości Dudy w Unii Wolności: To incydent, w: http://www.tvn24.p1/wiadomosci-zkraju,3/duda-w-unii-wolnosci-kaczynski-on-tego-nie-ukrywal,524620.html, 12 maja 2016.

Kaim P. (1993), Przeszłość odkreślamy gruba liniq, „Najwyższy Czas”, nr 44.

Kamińska-Szmaj I. (2001), Słowa na wolności. Język polityki po 1989 roku, Wydawnictwo Europa, Wrocław.

Kane J. (2004), The Politics of Moral Capital, Cambridge University Press, Cambridge.

Kern A. (1997), Krótka historia drużyny Lecha Watęsy, „Tygodnik Solidarność” 18 kwietnia, nr 16.

Krzaklewski M. (1996), Możemy wygrać - wywiad, „Życie” 9-11 listopada, nr 36.

Krzaklewski M. (2000), Moja Solidarność - wywiad, „Tygodnik Solidarność”, nr 35.

Krzaklewski M., Łętowski M., Zaremba P. (1997), Czas na akcję, Tysol, Warszawa.

Kwiatek W. (1997), Fantomy demokracji, „Nasza Polska” 28 maja, nr 22.

Kwiatek W. P. (1997), Fantomy demokracji, „Nasza Polska” 28 maja, nr 22.

Kwieciński J. (1994), Nowa Lewica i komuniści, „Gazeta Polska” 10 lutego, nr 6.

Kwieciński J. (1999), Bez wybaczenia. O Unii Wolności, „Gazeta Polska” 27 stycznia, nr 3.

Lipiński A. (2007), Das Phanomen der Kommunisten nach dem Kommunismus - die rechte Konstruktion eines linken Feindes in Polen nach 1989, w: Die Destruktion des Dialogs. Zur innenpolitischen Instrumentalisierung negativer Fremd- und Feindbilder. Polen, Tschechien, Deutschland und die Niederlande im Vergleich, 1900-2005, Wydawnictwo Harrassowitz Verlag, Wiesbaden.

Lipiński A. (2009), Dyskursywne konstruowanie tożsamości prawicy w warunkach podziału postkomunistycznego, w: Współczesne partie polityczne. Wybrane problemy, Wydawnictwo Adam Marszałek, Toruń (współautorstwo z T. Godlewskim, M. Jastrzębskim, I. Kapsą, D. Karnowską).

Lipiński Z. (1996), Prawica nie tylko zjednoczona, „Myśl Polska” 11 sierpnia, nr 32.

Ławiński P. (1990), Podstawy programu przyspieszenia, „Gazeta Wyborcza” 25 czerwca, nr 145. 
Macierewicz A. (1993), Gdy politykom brak odwagi, nastepne pokolenie płaci krwiq, w: J. Kurski, P. Semka, Lewy czerwcowy, Editions Spotkania, Warszawa.

Michalkiewicz S. (1996), „Drugi etap” budowy demokracji, „Najwyższy Czas” 2 marca, nr 9.

Michalkiewicz S. (1997), Anatomia kryzysu, „Najwyższy Czas” 22 lutego, nr 8.

Michnik A. (1997), Czas na akcję, czas na reakcję, „Gazeta Wyborcza” 12 września, nr 213.

Niesiołowski S. (1990), Reguly gry, „Ład” 10 czerwca, nr 23.

Niesiołowski S. (1994), Polsce potrzeba silnej, tradycyjnej prawicy, „Rzeczpospolita” 12 grudnia, nr 288.

Niesiołowski S. (2000), Odpowiedzialność, „Tygodnik AWS” 11 czerwca, nr 24.

Nyzio A. (2014), Rzadzić znaczy stużyć? Historia Unii Demokratycznej (1991-1994), Wydawnictwo PiT, Kraków.

Olszewski J. (1993), Mamy plan kształtowania Polski XXI wieku-przemówienie wygłoszone podczas konferencji RdR w dniu 24 stycznia 1993 r., w: Ruch dla Rzeczypospolitej. Materiaty programowe, Warszawa.

Olszewski J., Polak-Pałkiewicz E. (1997), Prosto w oczy, As Astra, Warszawa.

Oświadczenie ZChN (1991), „Gazeta Wyborcza” 15 marca, nr 63.

Pankowski K. (1997), Lewicowość - prawicowość: deklaracje polityczne Polaków 1990-1997, w: Prognozy i wybory. Polska demokracja '95, red. L. Kolarska-Bobińska, R. Markowski, Warszawa.

Panków I. (1998), Podziały w obozie solidarnościowym. Pluralizm polityczny a polityczna tożsamość, Instytut Studiów Politycznych PAN, Warszawa.

Pańków I. (1997), Narodziny posierpniowego pluralizmu: spór ,elitystów” z ,pluralistami”, w: Zbiorowi aktorzy polskiej polityki, red. J. Wasilewski, Instytut Studiów Politycznych PAN, Warszawa.

Parys J. (1994), Prawica, Kościót, Solidarność, „Najwyższy Czas”, nr 29.

Parys J. (1994b), Przebudzenie „Solidarności”- wywiad, „Gazeta Polska” 12 maja, nr 19.

Paszkiewicz K. A. (2000), Unia Demokratyczna, w: Partie i koalicje polityczne III Rzeczypospolitej, red. taż, Wydawnictwo Uniwersytetu Wrocławskiego, Wrocław.

Pawłowski J., Węgiełek J. (1990), Droga doniką, ,Tygodnik Solidarność” 5 stycznia, nr 1.

Romaszewski Z. (1996), Dlaczego byliśmy w KOR?, „Gazeta Polska” 11 lipca, nr 28.

Sakiewicz T. (1995), Różne oblicza Balcerowicza, „Gazeta Polska” 4 maja, nr 18.

Sergiejczyk P. (1998), Unia „patriotów”, „Nasza Polska” 16 września, nr 38.

Siergiejczyk P. (1996), ,, Solidarność” dla Polski, „Myśl Polska” 1 września, nr 31.

Siergiejczyk P. (1996), Socjal-liberałowie u władzy, „Myśl Polska” 14 stycznia, nr 2.

Siergiejczyk P. (1997), Blisko, coraz bliżej..., „Nasza Polska” 16 lipca, nr 29.

Siergiejczyk P. (1997), W stronę historycznego sojuszu?, „Myśl Polska” 8 czerwca, nr 23.

Sprawozdanie stenograficzne z 18 posiedzenia Sejmu w dniu 11 maja 2016 r., http://orka2.sejm.gov. pl/StenoInter8.nsf/0/B302B3DF054A54DBC1257FB0005DF994/\%24File/18_a_ksiazka.pdf, 15 maja 2016.

Szemplińska E. (1992), Lewa ręka, „Wprost” 23 sierpnia, nr 34.

Szulc A., Krzymowski M. (2015), Duda gracz, „Newsweek” 16-22 marca, nr 12.

Śpiewak P. (2000), Wojna na górze, „Przegląd Polityczny”, nr 46/47.

Trzy pytania do Ryszarda Bendera (1991), „Ład” 20 września, nr 38.

W.K. (1999), Chcq uczcić okragły stót, „Głos” 4 marca, nr 44,

Wałęsa L. (1990a), Prezydentem nie chce zostać... będę musiat zostać - wywiad, „Gazeta Wyborcza” 20 czerwca, $\mathrm{nr} 141$.

Wałęsa L. (1990b), ,,Solidarność” - drzewo nadziei, „Rzeczpospolita” 3 listopada, nr 204. 
Wawrzynowski R. (1997), Siedem grzechów głównych. Od SLD do UW, „Głos” 9 grudnia, nr 162. Wierzbicki P. (1990), Maska i frak, „Tygodnik Solidarność” 12 stycznia, nr 2.

Wierzbicki P. (1993), Dlaczego komuniści wygrali?, „Gazeta Polska” 23 stycznia, nr 32.

Wierzbicki P. (1995), Partia rzadzaca, „Gazeta Polska” 13 kwietnia, nr 15.

Wincławska M. (2010), Unia Wolności. Partia polityczna w okresie transformacji, Scholar, Warszawa.

Wrzodak Z. (1997), Różowe hieny, „Myśl Polska” 29 czerwca, nr 24.

Załuska W. (1994), Gra skrzydtami, „Gazeta Wyborcza” 7 lutego, nr 31.

Zaremba P. (1997), Szukajac sposobu na Unię, „Nowe Państwo” 22 maja, nr 21.

Zawisza A. (1996), Dlaczego warto być antykomunista?, „Myśl Polska” 31 marca, nr 13.

Zawisza A. (1996), Przypadek Unii Wolności, „Myśl Polska” 4 lutego, nr 5.

Zdort M., Reszka P. (1996), Otwarta lista „,Solidarności”, „Rzeczpospolita” 12 czerwca, nr 135.

\section{Strategies of „communisation” of the political enemy. The image of Freedom Union's millieu in the discourse of the Polish right}

\section{Summary}

Despite its long absence from the political scene Freedom Union is still used as a discursive figure constructed to polarize the public debate and party policy and discredit political opponents. The purpose of this paper is to show the genealogy and provide the analysis of the specific strategies of delegitimization using the figure of Freedom Union. These tasks will be achieved through the analysis of specific right wing strategies of building the image of Freedom Union the environment UW and its predecessors: Civic Movement Democratic Action and the Democratic Union.

Key words: political enemy construction, political parties, Freedom Union, discourse 
